\title{
Ecological drivers of spatial variability among fish fauna of 21 tropical Australian estuaries
}

\author{
Marcus Sheaves*, Ross Johnston \\ School of Marine and Tropical Biology, James Cook University, Townsville, Queensland 4811, Australia
}

\begin{abstract}
Tropical estuarine fish assemblages often show characteristic spatial variation at the scale of individual estuaries but there is no clear grouping of estuaries based on variables such as proximity or climatic conditions. This study investigates if such spatial patterns occur at more extensive spatial scales and begins to uncover the mechanisms driving these patterns. We sampled 21 estuaries spanning $650 \mathrm{~km}$ of the tropical northeastern coast of Australia that comprise 3 climatic zones and 7 discrete regions. The 21 estuaries possessed broadly similar fish assemblages; however, there was considerable variation in the details of faunal composition, species richness and catch per unit effort (CPUE) of individual species. This variation had little to do with an estuary's proximity to other sites or its climatic zone but was focussed at the estuary-to-estuary scale. The variability was largely a product of contrasting spatial patterns displayed by different species. In turn, the complex assemblage and species patterns seemed to be influenced in complex ways by contrasting responses to physical and ecological variables, with estuary-level ecological variables generally having greater power in explaining faunal differences than site-specific physical variables. The fact that estuary-level ecological variables produced a good explanation of the complex spatial patterns typical of tropical estuarine fauna indicates the value of developing estuary-scale explanatory variables that relate to specific ecological processes. The lack of any clear influence of climatic zone or proximity to other sites on spatial patterns highlights the continual need for careful evaluation of paradigmatic understanding.
\end{abstract}

KEY WORDS: Estuary · Tropical $\cdot$ Fish $\cdot$ Distribution $\cdot$ Composition $\cdot$ Scale

\section{INTRODUCTION}

Assemblages of organisms are structured by key biotic and abiotic processes (Holling 1992) that produce characteristic variability at specific spatial and temporal scales (Levin 1995). This scale-specific focussing of variability produces the spatial patchiness that is an essential and obvious property of nature (Dowling 1991). The mechanisms that control ecosystem patterns can be complex and may stem from collective behaviours of ensembles of smaller-scale units or be the result of larger-scale constraints (Levin 1995). Understanding these underlying mechanisms can be challenging but is essential to the understanding of ecological pattern and the evaluation of change. In well-studied parts of the world, process level understanding has been under development for many years.
However, in many tropical ecosystems, key patterns and processes are still neither clearly defined nor understood. In these ecosystems, the first steps to deeper understanding involve the identification of the characteristic scales of variability and the setting up of logical frameworks in which process level explanations can be explored.

Until recently, the characteristic scales of variation in tropical northern Australian estuarine fish assemblages could not be identified because faunal studies had been limited to one (Blaber 1980, Blaber et al. 1989, Sheaves 1992) or a few (Robertson \& Duke 1990, Sheaves 1998) estuaries. Recently, the spatial extent of studies has changed, with Ley (2005) considering 11 estuaries spanning some $1100 \mathrm{~km}$ of coast, and Sheaves (2006) including 9 estuaries spanning some $180 \mathrm{~km}$ of coastline. Although Sheaves (2006) only in- 
cluded a relatively short stretch of coastline $(200 \mathrm{~km})$, the sampling design explicitly comprised 3 nested spatial scales: among regions (adjacent groups of 3 estuaries), among adjacent estuaries within regions, and among replicates within estuaries. Additionally, the spatial arrangement of estuaries allowed preliminary evaluation of the extent of difference between the fauna of wet and dry tropical zones. This study showed characteristic variation at the scale of individual estuaries, with fish assemblages of estuaries within a region being not necessarily more similar than those of estuaries hundreds of kilometres apart, and with no grouping into wet and dry tropical assemblages. These estuary-to-estuary differences were pervasive, with individual estuaries maintaining their distinctive dry season faunal compositions over 3 yr despite a loss of faunal difference during the high recruitment summer wet season (Sheaves 2006). This repeated similarity of dry season assemblages was particularly striking because the study was dominated by juvenile fish that remained in the estuaries for only $1 \mathrm{yr}$. Despite the clear results, Sheaves was unable to discover a reasonable mechanism to explain the faunal patterns, which is clearly unsatisfactory.

The current study was conducted to determine if the spatial patterns reported by Sheaves (2006) could be generalised over more extensive spatial scales, in an effort to uncover the mechanisms driving these patterns. The study particularly aimed to (1) test whether variability in faunal structure could be best explained by a model focussed on estuary-scale landscape mechanisms, rather than proximate (similarity between adjacent estuaries) or regional (wet vs. dry tropics) spatial scales, (2) determine the extent of additional explanatory power represented by other spatial scales beyond the estuary scale, and (3) evaluate the proximate mechanisms for observed spatial patterns in faunal structure by determining which factors drive the patterns through a comparison of (a) the importance of a suite of site-specific physical and habitat variables on sampling site-level faunal patterns, and (b) the usefulness of a set of estuary-scale descriptors (derived by GIS), based on specific ecological theory, in explaining patterns of abundance. In evaluating these spatial patterns, interpretation is aimed at generalisation rather than concentrating on detailed faunal comparisons.

\section{MATERIALS AND METHODS}

Study area description. We sampled 21 estuaries spanning $650 \mathrm{~km}$ of the coast of tropical north Queensland, Australia (Fig. 1), including both wet and dry tropical areas. All estuaries had mangrove forests in their lower reaches and at least a narrow mangrove

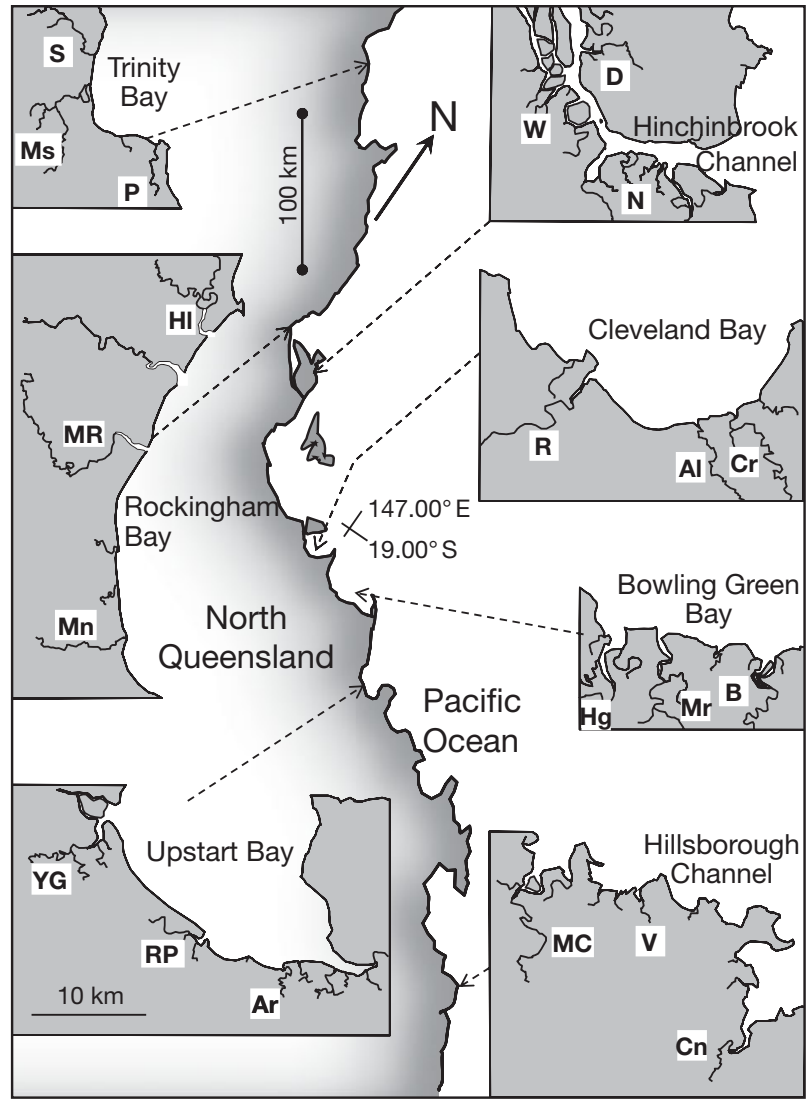

Fig. 1. Spatial distribution of the 21 study estuaries along the coast of north Queensland in tropical Australia. The vertical $100 \mathrm{~km}$ scale bar, the north arrow, and the latitude and longitude relate to the main coastal map. The horizontal $10 \mathrm{~km}$ scale bar relates to the inset maps of individual regions, which are all at the same scale. Estuary codes are given in Table 1

fringe $(<5 \mathrm{~m}$ wide) along the majority of their tidal extents. The dry tropical estuaries usually had extensive saltpans and saltmarshes adjacent to their mid and upper reaches, and along the inland fringes of their mangrove forests. In contrast, wet tropical estuaries were mangrove lined for most of their tidal lengths, usually with rainforest or farmland along their inland fringes. Mud and sand substrates dominated lower subtidal and intertidal areas, with only very isolated areas of rock and gravel. Tidal ranges increased from north to south, with the smallest range being $3.36 \mathrm{~m}$ in the north and the greatest range being $6.13 \mathrm{~m}$ in the south. All estuaries were relatively short (maximum tidal incursions between 3.7 and $25.6 \mathrm{~km}$ ) and narrow (maximum width $<200 \mathrm{~m}$ ), with depths at low tide being mainly $3 \mathrm{~m}$ or less (maximum depth $\sim 6 \mathrm{~m}$ for Neames Inlet). Catchment development varied from none around Deluge Inlet, which flows from an island national park, to extensive urban and industrial development adjacent to Ross River. Most estuaries had 
some level of development in their catchments, usually in the form of sugarcane plantations, cattle grazing pastures and/or sparse residential areas.

Sampling design. Three estuaries were situated in each of 7 regions spanning 3 climate zones (north wet, dry, south wet) on the tropical northeastern coast of Queensland (Fig. 1). The 7 regions represented discrete sections of coast containing groups of estuaries, and were defined as homogeneous geographical units that were separated by capes and/or headlands that potentially disrupted the continuity of coastal current flow, or consisted of discrete coastal waterways. Consequently, the influences of biological phenomena such as larval supply and physical environments were likely to differ among the regions selected (Sheaves 2006). Within estuaries, sampling was grouped into reaches representing downstream, upstream and mid estuary areas (Table 1). Thirteen of the estuaries were long enough to allow definition of all 3 reaches; however, only downstream and upstream reaches were defined in 7 shorter estuaries, and only the downstream reach was defined in 1 estuary (Victor Creek). Three sites were allocated in each reach and 10 samples were collected from each site. Thus, the sampling represented 6 hierarchically arranged spatial scales: zones (3), regions within zones (1 to 3 ), estuaries within

Table 1. Summary of regions, bays, estuaries, dates and reaches sampled. Estuary codes used in figures are given in brackets after the estuary name

\begin{tabular}{|c|c|c|c|}
\hline Region and Bay & Estuary & $\begin{array}{c}\text { Dates } \\
\text { (dd/mm/уyуy) }\end{array}$ & $\begin{array}{l}\text { No. of } \\
\text { reaches }\end{array}$ \\
\hline \multicolumn{4}{|c|}{ North wet tropics } \\
\hline \multirow[t]{3}{*}{ Trinity Bay } & Saltwater Creek (S) & $27 / 09 / 2007$ & 2 \\
\hline & Mossman River (Ms) & $27 / 09 / 2007$ & 2 \\
\hline & Packer Creek (P) & $28 / 09 / 2007$ & 2 \\
\hline \multirow{3}{*}{$\begin{array}{l}\text { Rockingham } \\
\text { Bay }\end{array}$} & Hull River (Hl) & $25 / 09 / 2007$ & 3 \\
\hline & Murray River (MR) & $29 / 08 / 2007$ & 3 \\
\hline & Meunga Creek (Mn) & $9 / 09 / 07,4 / 10 / 07$ & 2 \\
\hline \multirow{3}{*}{$\begin{array}{l}\text { Hinchinbrook } \\
\text { Channel }\end{array}$} & Deluge Inlet (D) & $31 / 08 / 07,8 / 10 / 07$ & 3 \\
\hline & Waterfall Creek (W) & $25 / 08 / 2007$ & 3 \\
\hline & Neames Inlet $(\mathrm{N})$ & $26 / 08 / 2007$ & 3 \\
\hline \multicolumn{4}{|l|}{ Dry tropics } \\
\hline \multirow[t]{3}{*}{ Cleveland Bay } & Ross River (R) & $24 / 09 / 07,6 / 10 / 07$ & 2 \\
\hline & Alligator Creek (Al) & $23 / 09 / 2007$ & 3 \\
\hline & Crocodile Creek (Cr) & $7 / 10 / 2007$ & 3 \\
\hline \multirow{3}{*}{$\begin{array}{l}\text { Bowling Green } \\
\text { Bay }\end{array}$} & Haughton River (Hg) & $12 / 09 / 2007$ & 3 \\
\hline & Morris Creek (Mr) & $11 / 09 / 2007$ & 3 \\
\hline & Barratta Creek (B) & $7 / 09 / 07,9 / 10 / 07$ & 3 \\
\hline \multirow[t]{3}{*}{ Upstart Bay } & Yellow Gin Creek (YG) & $10 / 09 / 2007$ & 3 \\
\hline & Rocky Ponds Creek (RP) & 8/09/2007 & 3 \\
\hline & Armstrong Creek (Ar) & $22 / 09 / 07,5 / 10 / 07$ & 3 \\
\hline \multicolumn{4}{|c|}{ South wet tropics } \\
\hline Hillsborough & Murray Creek (MC) & $11 / 10 / 2007$ & 2 \\
\hline \multirow[t]{2}{*}{ Channel } & Victor Creek (V) & $10 / 10 / 2007$ & 1 \\
\hline & Constant Creek (Cn) & $10 / 10 / 2007$ & 2 \\
\hline
\end{tabular}

regions (3), reaches within estuaries (number dependent on estuary length), sites within reaches (3), and samples within sites (10).

Reaches were $\sim 1.5 \mathrm{~km}$ long. Upstream samples were collected within $1.5 \mathrm{~km}$ of the upstream extent of navigation once water had receded from mangrove forests (approximately the limit of tidal incursion at MSL), downstream samples within $1.5 \mathrm{~km}$ of the estuary mouth, and mid-estuary samples approximately middistance between upstream and downstream reaches. Reaches were always sampled in an upstream to downstream sequence. Three sites were distributed evenly along each reach. To provide consistent representation among estuaries, sampling was conducted on the low angle banks $\left(\sim 10\right.$ to $\left.60^{\circ}\right)$ that comprised $\sim 80 \%$ of total bank length. Low angle banks consistently produce the highest catch rates in north Queensland estuaries (Johnston \& Sheaves 2008).

Sampling spanned 4 consecutive spring tide cycles between August and October 2007 (Table 1). This is the late dry season and provides a period where nekton assemblages in tropical estuaries are most stable and thus likely to provide the most reliable information about spatial differences in assemblages among estuaries (Sheaves 2006). Given the size of the sampling task, it was not possible to sample all estuaries repeatedly over time. However, Sheaves (2006) showed that north Queensland estuaries possessed distinct, estuary-specific faunal compositions that were repeated consistently from year to year. Thus, this study is based on the assumption that the samples collected were representative of the normal assemblages found in these estuaries. To validate this assumption, 5 estuaries ( 1 in each of the central bays) were sampled twice-once early and once late in the study. The order in which the central group of estuaries was sampled was completely randomised; however, because travelling time to and from Trinity Bay and Hillsborough Channel would use up days when tides were suitable for sampling, these estuaries were scheduled in groups at the ends of sampling periods (i.e. sequences of suitable tides within a lunar tidal cycle).

Using only one gear type would result in a biased sample of the full fish assemblage. It would be preferable to utilise a variety of sampling gears to allow the construction of a complete assemblage profile. However, given the spatial scope of the study, and the difficult sampling conditions, this was not reasonable. Instead, small mesh cast nets were used as this gear type could be employed across the greatest range of habitats (Johnston \& Sheaves 
2008) while producing the widest taxonomic and size representation possible (Sheaves et al. 2007). This means that the study probably provided good representation of the small and juvenile components that make up the bulk of fish in tropical estuarine assemblages (Blaber 1980, Robertson \& Duke 1990), but probably underrepresented larger mobile species that would be better collected with gill nets (Blaber et al. 1989, Ley 2005). Additionally, although cast nets can be used very close to highly complex habitats (snags, collapsed bank material), they are likely to underrepresent fauna that reside within complex habitats (Sheaves 1995).

Cast nets operated by the same individual were used for all nekton collection. Sampling was done from a $4.3 \mathrm{~m}$ boat that was fitted with an electric motor to reduce the potential for disturbance, and followed the protocols set out by Sheaves et al. (2007). Ten cast net samples were collected from each site using $2.4 \mathrm{~m}$ radius monofilament drawstring cast nets with $5 \mathrm{~mm}$ mesh. Sampling was confined to the lower half of ebbing spring tides, once tidal water had receded from the mangrove forests, to ensure that fish that use the forests would be sampled by the gear (Johnston \& Sheaves 2007). The exception to this was mudskippers (Family Gobiidae, subfamily Oxudercinae) that were mainly confined to exposed mud banks and mangrove forests at low tide, and were thus underrepresented in the samples.

Statistical analyses. The spatial fish data set comprised 2030 individual cast net samples which captured 118 fish species, many of which were schooling species. The capture of large numbers of schooling species presented potential problems. All gears that integrate over depths produce samples requiring corrections for different volumes sampled as the depth of water sampled changes. However, position in the water column and the vertical extent of schools differ among species (Arnold et al. 1997) and times (Newlands et al. 2006), making the validity of correcting for depth uncertain, particularly in the case of tropical estuaries where even average depth distributions are incompletely studied. Additionally, for fish that occur throughout the water column, correcting for the depth of water would be appropriate; however, for species that are only found in a narrow depth range (e.g. demersal species), uncorrected data would be more comparable. A second problem with schooling species is that the high concentration of abundance and biomass in a small volume means that hit-and-miss effects could lead to extremely variable estimates due to sampling error (Marchal \& Petitgas 1993). The relationship between realized sample size and the actual size of the school is uncertain because the proportion of the school sampled is unknown. Essentially, it is unclear whether observed differences in numbers captured indicate real differences in local abundance or simply result from chance differences in the proportion of the school sampled. To overcome the uncertainties in adjusting for depth and accounting for variability in catches of schooling species, analyses were based on presence per net sample rather than catch per unit effort (CPUE). Presences provide robust data when indices of relative abundance are of doubtful validity (Legendre \& Legendre 2003) because they treat species with a diversity of behaviours and patterns of spatial distribution in a more equivalent way than fully quantitative techniques (Manley et al. 2004). Additionally, this approach is appropriate in large-scale studies where most information in the data is contained in the presence-absence of species (McCune \& Grace 2002). Using presence per net sample meant that site became the basic sampling unit, with the dependent variable being the number of presences (i.e. out of 10 nets) of a species per site. This approach addresses a clear question about likelihood of encounter. Using presence per site rather than CPUE per net meant that one spatial scale (samples within sites) could not be evaluated; however, the trade-off was deemed acceptable due to the relative soundness of the assumptions required.

Spatial patterns in multivariate fish assemblage structure and the importance of explanatory data sets (see below) were analysed using multivariate classification and regression trees (mCARTs) (De'ath 2002) by utilising TreesPlus software. Multivariate analyses were conducted both based on raw presences (emphasising the number of occurrences) and on row standardised presences (emphasising relative occurrences) for the 24 species that occurred in $>10 \%$ of estuary $x$ reach combinations. Species richness was calculated as the number of species $(10 \text { nets })^{-1}$ in each site. All dependent variables were square root transformed to normalize the distribution of residuals. Species richness, individual species presences and the importance of explanatory data sets were analysed using univariate classification and regression trees (CARTs), again with square root transformed dependent variables. Selection of the final tree models was conducted using 10 -fold cross validation, with the 1-SE tree (the smallest tree with cross validation error within $1 \mathrm{SE}$ of that of the tree with the minimum cross validation error) being selected as the final tree model. This procedure produces valid, biologically interpretable trees (Breiman et al. 1984, De'ath 2002). The importance of each variable was evaluated by its occurrence in the final 1-SE tree. Additionally, the relative importance of variables was assessed to ensure that variables with high overall importance, which were not the best predictors for particular splits, were not overlooked. Importance was determined by using each variable at each tree 
branching, with the best overall classifier being given a relative importance of $100 \%$. CART analysis is based on a modelling rather than a hypothesis testing paradigm; thus, adjusting for multiple hypothesis tests is not an issue. However, since a large number of univariate CART models were constructed to investigate individual species responses, the structure of some models could appear similar by chance. Consequently, cautious interpretation is needed, thus only the general structure of the models and not their fine detail is interpreted here.

CART analyses indicated assemblage differences between upstream and downstream reaches. Nonmetric multidimensional scaling (nMDS, Bray Curtis similarities, square root transformed occurrences using Primer 6 software) was employed to investigate the nature of this pattern. Information on the strength and nature of the correlation of species with the nMDS space was added to the ordination biplot as vectors indicating the direction of greatest increase in occurrence of species most highly correlated with the space. The directions of these vectors were determined by multiple regression of each species on the nMDS space, with the length of vectors reflecting the $\mathrm{R}^{2}$ value for each regression, thus indicating the strength of the correlation.
As with the spatial explanatory variables, the study used 3 explanatory data sets: site-scale physical, estuaryscale ecological and estuary-scale potential for impact.

Site-scale physical variables: These comprised turbidity, salinity, bank profile, depth, substrate, cross channel profile and site-level sinuosity. Bank profile was the slope (shallow $<250^{\circ}$, medium $250-750^{\circ}$, steep $\left.>750^{\circ}\right)$ of the shallow water $(<1 \mathrm{~m})$ margin of the estuary at different tidal stages (high/mid/low tide). Depth was calculated as the mean for each site at the time of sampling. Substrate was categorised as either sand or mud. Cross channel profiles were defined as (a) heterogeneous (1 steep and 1 low angle bank), (b) low relief basins (both banks having $<45^{\circ}$ slopes), or (c) high relief basins (both banks having $>45^{\circ}$ slopes). Site-level sinuosity involved categorising each site as comprising a straight section of channel, a medium angled bend, or a sharp angled bend. Although salinity and turbidity only represented snapshots of conditions at each site, and were thus likely to be poor indicators of important trends (Sheaves 1996), they were included as the best available indicators of the physical conditions prevailing at the sites at the time of sampling. To characterise the similarities and differences between estuaries, the relationship between site-scale physical variables (averaged over reaches) and spatial

Table 2. Estuary-level characteristics of the 21 estuaries (see Table 3 for definitions of variables and meanings of abbreviations)

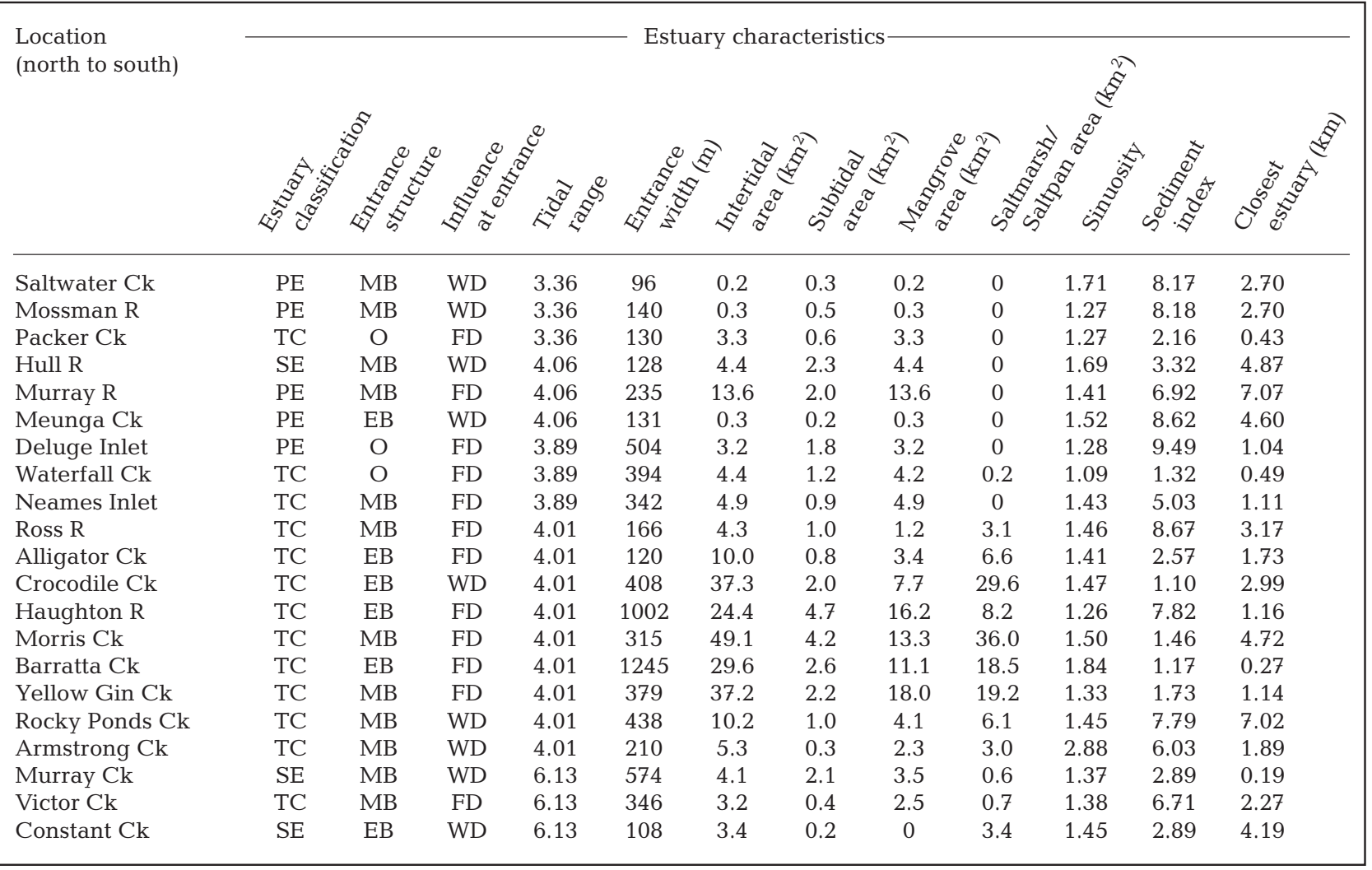


variables were investigated using principal component analysis (PCA) ordination employing Primer 6 software, with the data being normalised before analysis.

Estuary-scale ecological variables: Most of the estuaries studied were not classified in the OzEstuaries data base (Anon 2008), which is the most comprehensive classification of Australian estuaries. For those that were, the general nature of classifications in the OzEstuaries data base did not fit well with specific onground understanding of the study systems. Moreover, these classifications are mainly based on physical attributes that are not defined in terms of specific ecological processes. Consequently, 12 estuary-scale ecologi- cal characteristics were defined based on their likely influence on specific ecological processes (Table 2). These included both redefined variables featured in OzEstuaries and newly defined variables (Table 3). Definition and quantification of the variables were accomplished by using freely available remote imagery (Google Earth) and aerial photographic images, which were supported by detailed ground truthing (at least $1 \mathrm{~d}$ in each estuary system). Distances and areas were calculated from digitised images using SigmaScan Pro.

Estuary-scale potential for impact: There has been little quantification of human impacts on estuaries in the study area. Consequently, a set of variables was

Table 3. Definitions of estuary-scale ecological variables

\begin{tabular}{|c|c|c|}
\hline Variable & Definition & Ecological processes influenced \\
\hline $\begin{array}{l}\text { Estuary } \\
\text { classification }\end{array}$ & $\begin{array}{l}\text { Permanent estuary (PE): freshwater inflow permanent - catchment } \\
<10000 \mathrm{~km}^{2} \\
\text { Seasonal estuary (SE): freshwater inflow seasonal — catchment area } \\
>10000 \mathrm{~km}^{2} \\
\text { Tidal creek (TC): freshwater inflow not sustained even in wet season } \\
\text { but links to ephemeral drainage systems }\end{array}$ & $\begin{array}{l}\text { Migration, recruitment, extent and } \\
\text { type of nutrient subsidies, physical } \\
\text { environment }\end{array}$ \\
\hline $\begin{array}{l}\text { Entrance } \\
\text { structure }\end{array}$ & $\begin{array}{l}\text { Open (O): intertidal sand/mud flats adjacent to main channel extend } \\
<250 \mathrm{~m} \text { seaward from entrance at mean low water spring tide (MLWS) } \\
\text { Minor barrier (MB): intertidal sand/mud flats extend } 250-1000 \mathrm{~m} \text { at } \\
\text { MLWS } \\
\text { Extensive barrier (EB): intertidal sand/mud flats extend }>1000 \mathrm{~m} \text { at } \\
\text { MLWS }\end{array}$ & $\begin{array}{l}\text { Migration, recruitment, extent of } \\
\text { tidal influence and water exchange }\end{array}$ \\
\hline $\begin{array}{l}\text { Influence at } \\
\text { entrance }\end{array}$ & $\begin{array}{l}\text { Flow dominated (FD): a clear channel ( }>1 \mathrm{~m} \text { deep at shallowest point) } \\
\text { connects to coastal waters at MLWS } \\
\text { Wave dominated (WD): no clear channel ( }>1 \mathrm{~m} \text { deep) connecting to } \\
\text { coastal waters }\end{array}$ & \\
\hline Tidal range & $\begin{array}{l}\text { Difference between mean high water springs and mean low water } \\
\text { springs }\end{array}$ & \\
\hline $\begin{array}{l}\text { Entrance } \\
\text { width }\end{array}$ & $\begin{array}{l}\text { Measured at the MSL from the most landward bank (at the point } \\
\text { where the MSL line changes direction away from the estuary to align } \\
\text { with the general direction of the coast) perpendicular to the estuary } \\
\text { channel to the MSL line on the opposite bank. }\end{array}$ & \\
\hline $\begin{array}{l}\text { Intertidal } \\
\text { area }\end{array}$ & $\begin{array}{l}\text { Maximum extent of mangroves, saltmarshes and saltpans. Expressed } \\
\text { relative to perimeter of subtidal area. }\end{array}$ & \\
\hline $\begin{array}{l}\text { Subtidal } \\
\text { area }\end{array}$ & $\begin{array}{l}\text { The area of water at mean sea level. Expressed relative to perimeter } \\
\text { of subtidal area. }\end{array}$ & $\begin{array}{l}\text { Utilisation of intermittently } \\
\text { available refuge/feeding habitats }\end{array}$ \\
\hline $\begin{array}{l}\text { Mangrove } \\
\text { area }\end{array}$ & $\begin{array}{l}\text { Area of continuous mangrove forest with closed canopy. Expressed } \\
\text { relative to perimeter of subtidal area. }\end{array}$ & \\
\hline $\begin{array}{l}\text { Saltmarsh/ } \\
\text { saltpan area }\end{array}$ & $\begin{array}{l}\text { Intertidal area above MSL without mangrove forest (includes sparse } \\
\text { mangrove growth). Expressed relative to perimeter of subtidal area. }\end{array}$ & \\
\hline Sinuosity & $\begin{array}{l}\text { Ratio of estuary mid-channel length to straight line distance between } \\
\text { points of inflection of bends along estuary length }\end{array}$ & $\begin{array}{l}\text { High sinuosity provides more sites } \\
\text { where bank erosion produces } \\
\text { 'snaggy' habitats and more } \\
\text { complex bank and bed architec- } \\
\text { ture and hydrodynamic complexity }\end{array}$ \\
\hline $\begin{array}{l}\text { Sediment } \\
\text { index }\end{array}$ & $\begin{array}{l}\text { Mean of ranks of sediment sizes from fine mud (1) to coarse sand (10) } \\
\text { based on predominant substrate type recorded every } 250 \mathrm{~m} \text { along } \\
\text { estuary on lowest angle bank. Measurements commence } 250 \mathrm{~m} \\
\text { upstream to exclude sediments migrating along the coast. }\end{array}$ & $\begin{array}{l}\text { Suitability for sediment specialists, } \\
\text { composition of benthic food webs }\end{array}$ \\
\hline $\begin{array}{l}\text { Closest } \\
\text { estuary }\end{array}$ & $\begin{array}{l}\text { Shortest possible distance by coastal waters to the nearest system } \\
\text { fitting one of the estuary classifications }\end{array}$ & Recruitment, migration \\
\hline
\end{tabular}


defined based on the perceived potential for human impact, which was estimated from the percentage of the estuaries' upper intertidal perimeters with potential anthropogenic stressors adjacent to them (derived from remote imagery). The variables defined were the percentage of perimeter with adjacent aquaculture, improved pasture/cropping/horticulture, unimproved pasture and urban/industrial development, and total anthropogenic development.

\section{RESULTS}

\section{Physical variability}

Salinity profiles did not match well with expectations of differences between wet and dry tropics. Although 5 of the north wet tropical estuaries showed salinities below normal seawater and a typical upstream salinity gradient (i.e. salinities decreasing in an upstream direction), 3 others did not. Similarly, although most dry tropical estuaries were hypersaline with inverse salinity gradients, some showed salinities around normal seawater and a typical upstream salinity gradient, with one (Barratta Creek) showing a salinity pattern much more like the 'typical' wet tropical sites. Southern wet tropical sites had salinities around that of normal seawater with no upstream gradient. Turbidity showed even less spatial pattern, with a variety of turbidity ranges and degrees of spatial variability, and inconsistent patterns of upstream turbidity change across the 3 reaches. Temperature showed little variation except for a small $\left(<2^{\circ} \mathrm{C}\right)$ sequential temperature increase over the course of the study that bore no relation to patterns of faunal difference.

PCA ordination, using site-level physical variables, showed a pattern of variation in spatial variables related to the interactive effects of zone (wet/dry tropics) and reach (upstream/downstream) (Fig. 2a). Site-level sinuosity and turbidity, which were negatively correlated, and salinity, which was uncorrelated with the other 2 variables, were the only site-level environmental variables that explained a substantial component of spatial variation. Upstream northern wet tropical sites were highly sinuous, had low turbidities and showed the greatest variation in salinity, suggesting less stable environmental regimes. Downstream northern wet tropical sites had generally higher salinities and wide ranges of turbidities and degrees of site-level sinuosity. Upstream and downstream dry tropical and southern wet tropical sites showed similar ranges of turbidities and site-level sinuosities as downstream northern wet topics sites but had generally higher salinities.

Taking a regional view (Fig. 2b), there were substantial physical differences between upstream and down-
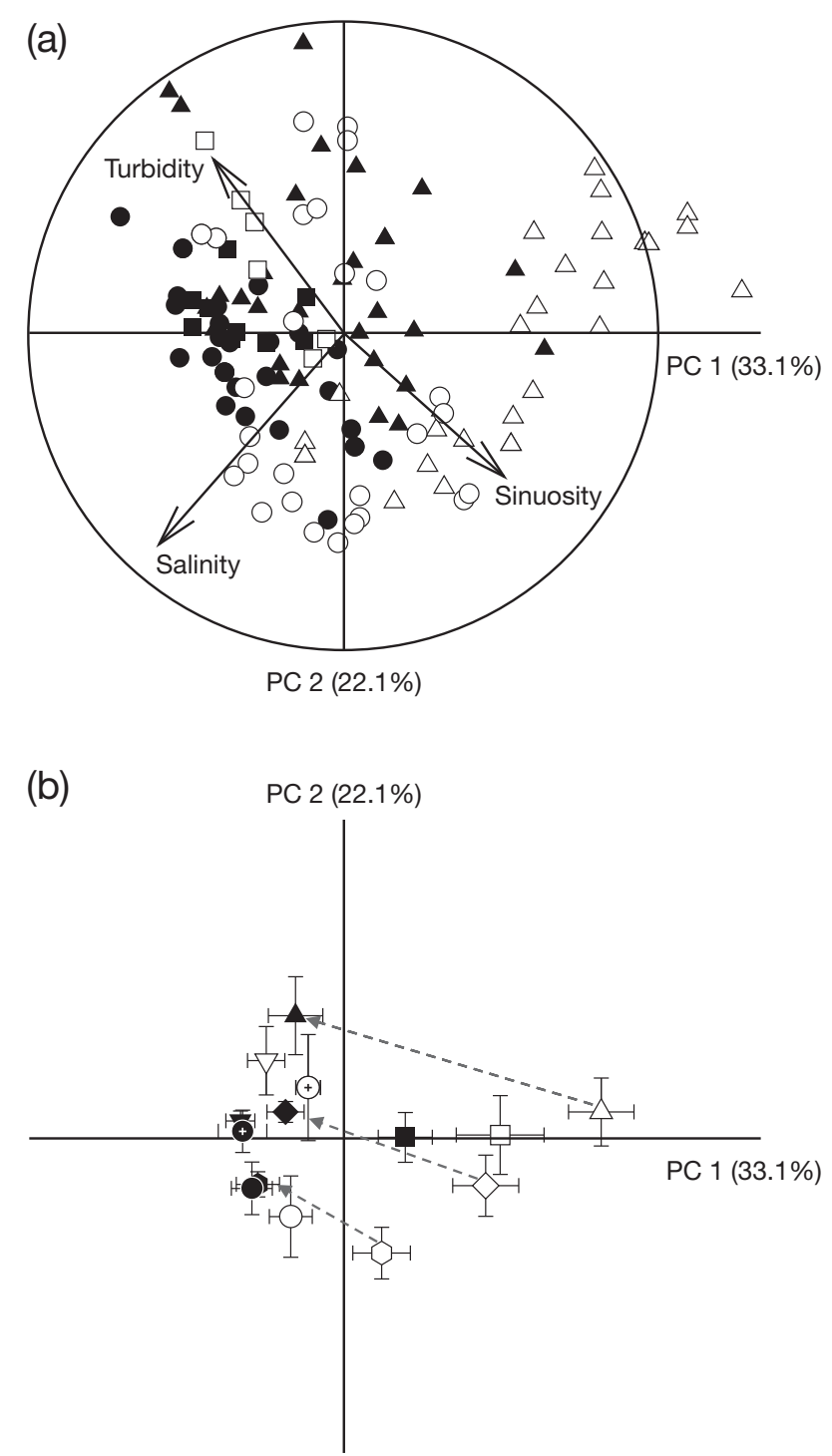

Fig. 2. Principal component analysis (PCA) ordinations for the relationships among reaches relative to site-scale variables averaged over reaches (upstream and downstream only). (a) Individual reaches coded by region: $(O, \bullet)$ dry tropics, $(\Delta, \mathbf{\Lambda})$ north wet tropics, $(\square, \boldsymbol{\square})$ south wet tropics; filled symbols: downstream, unfilled symbols: upstream. Vectors indicate the direction of greatest increase of the factors most highly correlated with the ordination space. Vector lengths indicate the magnitude of correlations relative to the unit circle. (b) Bay centroids $( \pm 1$ SE): $(O, \bullet)$ Upstart, $(\square, \boldsymbol{\square})$ Trinity, $(\Delta, \mathbf{\Delta})$ Rockingham, $(\nabla, \nabla)$ Hillsborough, $(\diamond$,$) Hinchinbrook, (\square, \boldsymbol{)})$ Cleveland, $(\oplus, \boldsymbol{\oplus})$ Bowling Green. (४--) Bays with substantial upsteam to downstream differences; filled symbols: downstream, unfilled symbols: upstream

stream sites in Rockingham Bay and Hinchinbrook Channel (northern wet tropics), a smaller difference in Cleveland Bay (dry tropics) but only minor upstreamdownstream differences in the other bays. Overall, downstream reaches tended to have higher turbidity but were less sinuous than upstream reaches. 


\section{Biological data}

During the study, 15624 fish comprising 118 species from 46 families were captured, including mainly large juveniles that were between 25 and $125 \mathrm{~mm}$ in fork length (FL). Repeat sampling of 5 estuaries (Fig. 3) produced similar profiles of numbers of presences, suggesting that the composition was stable over the sampling period and that sampling represented the target fauna well.

A characteristic estuarine fauna was identifiable across the study estuaries, with 15 species occurring in $2 / 3$ or more of the estuaries and another 15 occurring

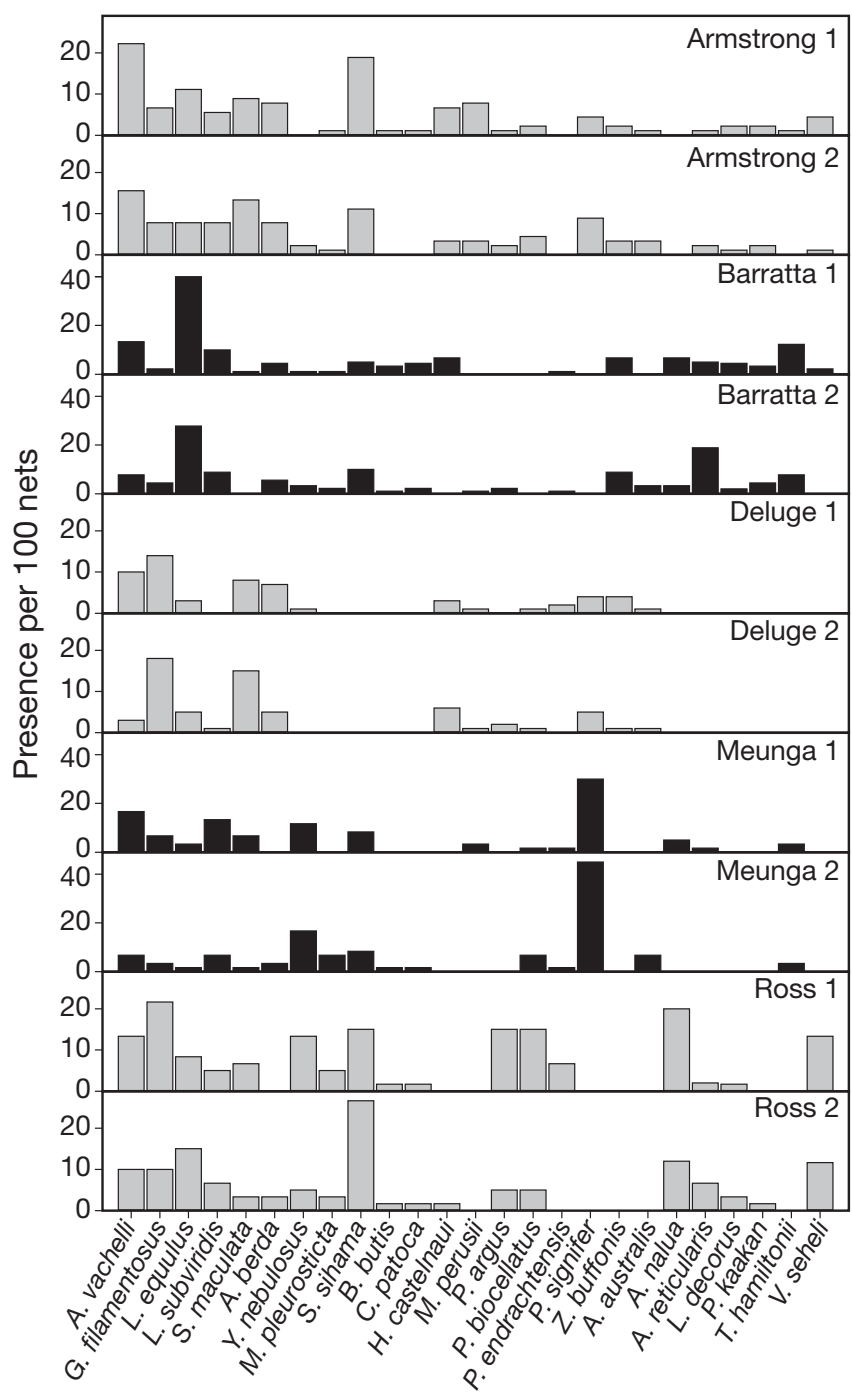

Fig. 3. Species profiles (presence per 100 nets) for 25 species that occurred in $>10 \%$ of estuary $\times$ reach combinations from 5 estuaries that were sampled on 2 occasions. Alternate pairs of figures with grey or black bars indicate 2 samples from the same estuary. $P$. endrachtensis = Platycephalus endrachtensis, A. reticularis $=$ Arothron reticularis; other species names are given in full in Table 4 in $1 / 3$ to $2 / 3$ of the estuaries (Table 4 ). Families with multiple representatives included Leiognathidae (4 spp.), Mugilidae (4 spp.), Tetraodontidae (3 spp.), and Ambassidae, Clupeidae, Gobiidae, Haemulidae, Sparidae, and Sillaginidae (2 spp. each) (see Table S1 in supplementary material at www.int-res.com/articles/ suppl/m385p245_app.pdf for CPUE per estuary).

\section{Spatial patterns}

Species richness

Spatial factors explained $55 \%$ of the variability in species richness (Fig. 4). Site-level species richness was primarily influenced by estuary and reach, with the same reach split on each branch of the initial estuary split, indicating that the effect of reach was independent of estuary. In each case, downstream reaches had higher species richness than upstream or mid reaches. Neither zone

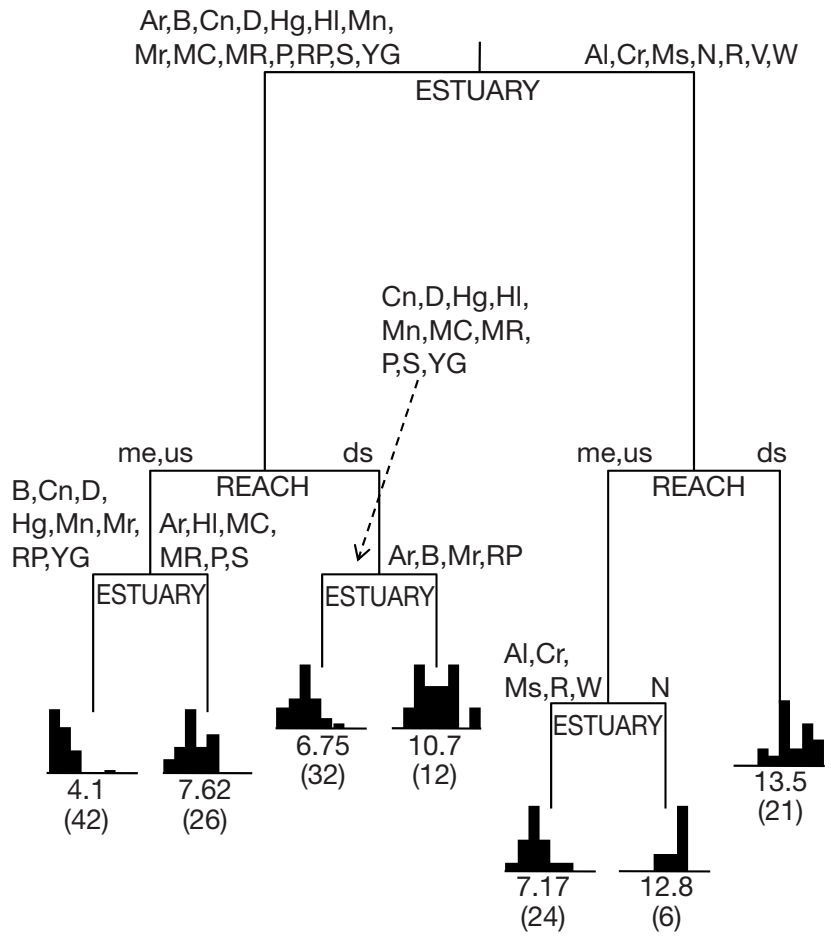

Fig. 4. Univariate classification and regression trees (CART) based on spatial variables explaining $55 \%$ of the variation in species richness for 21 estuaries. Histograms below terminal branches indicate the frequency distributions of species richness ( 9 categories from $0<x<3$ species, to $32<x<35$ species), numbers below terminal branches are mean species richness estimates for each branch, and numbers in brackets indicate the number of sites grouped in each terminal branch. Factors responsible for splits are indicated in uppercase letters below branch points. Codes above branches indicate levels of factors split in each direction. Reach codes: ds = downstream, me = mid estuary, us = upstream. Estuary codes are given in Table 1 


\begin{tabular}{|c|c|c|c|c|c|c|c|c|c|c|c|c|c|c|c|c|c|c|c|c|c|c|c|}
\hline & 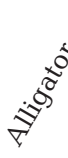 & है & ब્ & $\overbrace{}^{2}$ & ర্ & $\overbrace{}^{2}$ & 尔 & 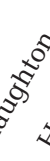 & $\frac{\vec{\sigma}}{5}$ & مَ & $y_{1}^{2}$ & है & है & 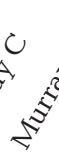 & 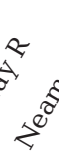 & $Q^{d}$ & से & 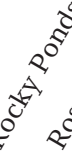 & के & $5^{\frac{\sigma^{\prime}}{3}}$ & فَّ & 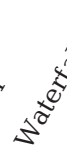 & స: \\
\hline \multicolumn{24}{|l|}{ (a) 66.6 to $100 \%$} \\
\hline Ambassis vachelli & $\mathrm{x}$ & $\mathrm{x}$ & $\mathrm{x}$ & $\mathrm{x}$ & $\mathrm{x}$ & $\mathrm{x}$ & $\mathrm{x}$ & $\mathrm{x}$ & $\mathrm{x}$ & & $\mathrm{x}$ & $\mathrm{x}$ & $\mathrm{x}$ & $\mathrm{x}$ & $\mathrm{x}$ & $\mathrm{X}$ & $\mathrm{x}$ & $\mathrm{x}$ & $\mathrm{x}$ & $\mathrm{x}$ & $\mathrm{x}$ & $\mathrm{x}$ & $\mathrm{x}$ \\
\hline Leiognathus equulus & $\mathrm{x}$ & $\mathrm{x}$ & $\mathrm{x}$ & & $\mathrm{x}$ & $\mathrm{x}$ & $\mathrm{x}$ & $\mathrm{x}$ & $\mathrm{x}$ & & $\mathrm{x}$ & $\mathrm{x}$ & $\mathrm{x}$ & $\mathrm{x}$ & $\mathrm{x}$ & $\mathrm{x}$ & $\mathrm{x}$ & $\mathrm{x}$ & $\mathrm{x}$ & $\mathrm{x}$ & $\mathrm{x}$ & $\mathrm{x}$ & $\mathrm{x}$ \\
\hline Acanthopagrus berda & $\mathrm{x}$ & $\mathrm{x}$ & $\mathrm{x}$ & $\mathrm{x}$ & $\mathrm{x}$ & $\mathrm{x}$ & $\mathrm{x}$ & $\mathrm{x}$ & $\mathrm{x}$ & & & $\mathrm{x}$ & $\mathrm{x}$ & $\mathrm{x}$ & $\mathrm{x}$ & $\mathrm{x}$ & $\mathrm{x}$ & $\mathrm{x}$ & $\mathrm{x}$ & $\mathrm{x}$ & $\mathrm{x}$ & $\mathrm{x}$ & $\mathrm{x}$ \\
\hline Liza subviridis & $\mathrm{x}$ & $\mathrm{x}$ & $\mathrm{x}$ & $\mathrm{x}$ & $\mathrm{x}$ & $\mathrm{x}$ & $\mathrm{x}$ & $\mathrm{x}$ & $\mathrm{x}$ & & $\mathrm{x}$ & $\mathrm{x}$ & & $\mathrm{x}$ & $\mathrm{x}$ & x & & $\mathrm{x}$ & $\mathrm{x}$ & $\mathrm{x}$ & $\mathrm{x}$ & & $\mathrm{x}$ \\
\hline Sillago sihama & $\mathrm{x}$ & $\mathrm{x}$ & $\mathrm{x}$ & $\mathrm{x}$ & $\mathrm{x}$ & & $\mathrm{x}$ & $\mathrm{x}$ & $\mathrm{x}$ & & & $\mathrm{x}$ & $\mathrm{x}$ & $\mathrm{x}$ & $\mathrm{x}$ & $\mathrm{x}$ & $\mathrm{x}$ & $\mathrm{x}$ & $\mathrm{x}$ & $\mathrm{x}$ & & $\mathrm{x}$ & $\mathrm{x}$ \\
\hline Zenarchopterus buffonis & $\mathrm{x}$ & $\mathrm{x}$ & $\mathrm{x}$ & $\mathrm{x}$ & $\mathrm{x}$ & $\mathrm{x}$ & $\mathrm{x}$ & $\mathrm{x}$ & & & $\mathrm{x}$ & & $\mathrm{x}$ & $\mathrm{x}$ & $\mathrm{x}$ & $\mathrm{x}$ & $\mathrm{x}$ & $\mathrm{x}$ & & & $\mathrm{x}$ & $\mathrm{x}$ & $\mathrm{x}$ \\
\hline Gerres filamentosus & $\mathrm{x}$ & $\mathrm{x}$ & $\mathrm{x}$ & & $\mathrm{x}$ & $\mathrm{x}$ & $\mathrm{x}$ & $\mathrm{x}$ & $\mathrm{x}$ & & & $\mathrm{X}$ & & $\mathrm{x}$ & $\mathrm{x}$ & $\mathrm{x}$ & $\mathrm{x}$ & $\mathrm{x}$ & $\mathrm{x}$ & $\mathrm{x}$ & & $\mathrm{x}$ & \\
\hline Herklotsichthys castelnaui & $\mathrm{x}$ & $\mathrm{x}$ & $\mathrm{x}$ & $\mathrm{x}$ & $\mathrm{x}$ & $\mathrm{x}$ & & $\mathrm{x}$ & & & $\mathrm{x}$ & & $\mathrm{x}$ & $\mathrm{x}$ & $\mathrm{x}$ & $\mathrm{x}$ & $\mathrm{x}$ & $\mathrm{x}$ & $\mathrm{x}$ & $\mathrm{x}$ & & $\mathrm{x}$ & \\
\hline Leiognathus decorus & $\mathrm{x}$ & $\mathrm{x}$ & $\mathrm{x}$ & $\mathrm{x}$ & & & $\mathrm{x}$ & $\mathrm{x}$ & & & $\mathrm{x}$ & $\mathrm{x}$ & $\mathrm{x}$ & $\mathrm{x}$ & $\mathrm{x}$ & x & & & $\mathrm{x}$ & $\mathrm{x}$ & $\mathrm{x}$ & $\mathrm{x}$ & $\mathrm{X}$ \\
\hline Pseudomugil signifer & $\mathrm{x}$ & $\mathrm{x}$ & & & $\mathrm{X}$ & $\mathrm{X}$ & & $\mathrm{x}$ & $\mathrm{X}$ & & $\mathrm{x}$ & $\mathrm{x}$ & & $\mathrm{x}$ & $\mathrm{x}$ & x & & $\mathrm{x}$ & & $\mathrm{x}$ & $\mathrm{x}$ & $\mathrm{x}$ & $\mathrm{x}$ \\
\hline Yongeichthys nebulosus & $\mathrm{x}$ & $\mathrm{x}$ & $\mathrm{x}$ & & & $\mathrm{x}$ & & $\mathrm{x}$ & $\mathrm{x}$ & & $\mathrm{x}$ & $\mathrm{x}$ & & & $\mathrm{x}$ & $\mathrm{x}$ & $\mathrm{x}$ & & $\mathrm{x}$ & & $\mathrm{x}$ & $\mathrm{x}$ & $\mathrm{x}$ \\
\hline Moolgarda perusii & & $\mathrm{x}$ & $\mathrm{x}$ & $\mathrm{x}$ & $\mathrm{x}$ & $\mathrm{x}$ & & $\mathrm{x}$ & $\mathrm{x}$ & & & $\mathrm{x}$ & $\mathrm{x}$ & & $\mathrm{x}$ & x & & $\mathrm{x}$ & & & $\mathrm{x}$ & $\mathrm{x}$ & $\mathrm{x}$ \\
\hline Psammogobius biocellatus & & $\mathrm{x}$ & & & & $\mathrm{x}$ & & $\mathrm{x}$ & $\mathrm{x}$ & & & $\mathrm{x}$ & & $\mathrm{x}$ & $\mathrm{x}$ & $\mathrm{X}$ & $\mathrm{x}$ & $\mathrm{x}$ & $\mathrm{x}$ & $\mathrm{x}$ & $\mathrm{x}$ & $\mathrm{x}$ & $\mathrm{x}$ \\
\hline Pomadasys kaakan & $\mathrm{x}$ & $\mathrm{x}$ & $\mathrm{x}$ & & $\mathrm{x}$ & & $\mathrm{x}$ & $\mathrm{x}$ & & & & $\mathrm{x}$ & & $\mathrm{x}$ & $\mathrm{x}$ & $\mathrm{x}$ & & $\mathrm{x}$ & $\mathrm{x}$ & & $\mathrm{x}$ & $\mathrm{x}$ & $\mathrm{x}$ \\
\hline Ambassis nalua & $\mathrm{x}$ & & $\mathrm{x}$ & & $\mathrm{x}$ & & $\mathrm{x}$ & $\mathrm{x}$ & $\mathrm{x}$ & & $\mathrm{x}$ & $\mathrm{x}$ & & $\mathrm{X}$ & $\mathrm{x}$ & $x$ & & & $\mathrm{x}$ & & & $\mathrm{x}$ & $\mathrm{x}$ \\
\hline \multicolumn{24}{|l|}{ (b) 33.3 to $66.5 \%$} \\
\hline Valamugil seheli & $\mathrm{x}$ & $\mathrm{x}$ & $\mathrm{x}$ & $\mathrm{x}$ & $\mathrm{x}$ & & & $\mathrm{x}$ & & & $\mathrm{x}$ & $\mathrm{x}$ & & & $\mathrm{x}$ & $\mathrm{x}$ & & $\mathrm{x}$ & $\mathrm{x}$ & $\mathrm{x}$ & & $\mathrm{x}$ & \\
\hline Leiognathus splendens & & & $\mathrm{x}$ & & $\mathrm{x}$ & & & $\mathrm{x}$ & & & $\mathrm{x}$ & $\mathrm{x}$ & $\mathrm{x}$ & $\mathrm{x}$ & $\mathrm{x}$ & x & & & $\mathrm{x}$ & $\mathrm{x}$ & $\mathrm{x}$ & $\mathrm{x}$ & $\mathrm{x}$ \\
\hline Sillago maculata & $\mathrm{x}$ & $\mathrm{x}$ & $\mathrm{x}$ & & & $\mathrm{x}$ & & $\mathrm{x}$ & $\mathrm{x}$ & & & $\mathrm{x}$ & & & & & & $\mathrm{x}$ & $\mathrm{x}$ & $\mathrm{x}$ & & $\mathrm{x}$ & $\mathrm{x}$ \\
\hline Thryssa hamiltonii & $\mathrm{x}$ & $\mathrm{x}$ & $\mathrm{x}$ & $\mathrm{x}$ & & & $\mathrm{x}$ & & $\mathrm{x}$ & & $\mathrm{x}$ & $\mathrm{x}$ & $\mathrm{x}$ & $\mathrm{x}$ & $\mathrm{x}$ & x & & & & & & & $\mathrm{x}$ \\
\hline Marilyna pleurosticta & & $\mathrm{x}$ & $\mathrm{x}$ & $\mathrm{x}$ & $\mathrm{x}$ & & $\mathrm{x}$ & $\mathrm{x}$ & & & & & $\mathrm{x}$ & & $\mathrm{x}$ & x & & & $\mathrm{x}$ & $\mathrm{x}$ & & & \\
\hline Pseudorhombus argus & $\mathrm{x}$ & $\mathrm{x}$ & & $\mathrm{x}$ & $\mathrm{x}$ & & $\mathrm{x}$ & $\mathrm{x}$ & & & $\mathrm{x}$ & $\mathrm{x}$ & & & & & & $\mathrm{x}$ & $\mathrm{x}$ & & & & \\
\hline Acanthopagrus australis & $\mathrm{x}$ & $\mathrm{x}$ & & $\mathrm{x}$ & $\mathrm{x}$ & $\mathrm{x}$ & $\mathrm{x}$ & & & & & & $\mathrm{x}$ & & & & & $\mathrm{x}$ & & & $\mathrm{x}$ & & $\mathrm{x}$ \\
\hline Chelonodon patoca & $\mathrm{x}$ & $\mathrm{x}$ & $\mathrm{x}$ & & $\mathrm{x}$ & & & & & & $\mathrm{x}$ & $\mathrm{x}$ & & $\mathrm{x}$ & $\mathrm{x}$ & x & & & $\mathrm{x}$ & $\mathrm{x}$ & & & \\
\hline Nematalosa come & $\mathrm{x}$ & $\mathrm{x}$ & & & $\mathrm{x}$ & & $\mathrm{x}$ & & & & $\mathrm{x}$ & $\mathrm{x}$ & $\mathrm{x}$ & & $\mathrm{x}$ & x & $x$ & & & & & $\mathrm{x}$ & \\
\hline Tetractenos hamiltoni & $\mathrm{x}$ & $\mathrm{x}$ & $\mathrm{x}$ & $\mathrm{x}$ & $\mathrm{x}$ & & & & & & $\mathrm{x}$ & & & & & & & $\mathrm{x}$ & & & $\mathrm{x}$ & & $\mathrm{x}$ \\
\hline Butis butis & $\mathrm{x}$ & $\mathrm{x}$ & $\mathrm{x}$ & & & & & & & & $\mathrm{x}$ & & $\mathrm{x}$ & & & & $\mathrm{x}$ & & $\mathrm{x}$ & & $\mathrm{x}$ & & \\
\hline Lutjanus russellii & $\mathrm{x}$ & $\mathrm{x}$ & $\mathrm{x}$ & & & $\mathrm{x}$ & & & & & $\mathrm{x}$ & & & & $\mathrm{x}$ & $\mathrm{x}$ & & & & & $\mathrm{x}$ & $\mathrm{x}$ & \\
\hline Gazza minuta & & $\mathrm{x}$ & $\mathrm{x}$ & & & & & $\mathrm{x}$ & & & & $\mathrm{x}$ & & & $\mathrm{x}$ & x & $\mathrm{x}$ & & & $\mathrm{x}$ & & $\mathrm{x}$ & \\
\hline Siganus lineatus & $\mathrm{x}$ & & $\mathrm{x}$ & & & $\mathrm{x}$ & & $\mathrm{x}$ & & & & & & & & & $\mathrm{x}$ & & & & $\mathrm{x}$ & $\mathrm{x}$ & \\
\hline Pomadasys argenteus & $\mathrm{x}$ & $\mathrm{x}$ & & & & & & $\mathrm{x}$ & & & & $\mathrm{x}$ & & & $\mathrm{x}$ & $\mathrm{x}$ & & & & $\mathrm{X}$ & & $\mathrm{x}$ & \\
\hline
\end{tabular}

nor region was important in explaining the pattern of species richness. While the initial estuary split separated a group of 7 high richness estuaries from the remainder, neither group was distinct in terms of the other spatial variables, with the high richness group comprising estuaries from both wet and dry tropics and from 4 different regions. Similarly, subsequent estuary splits produced groups comprised of combinations of zones and regions. This pattern of species richness, with downstream reaches being more species rich than mid and upstream reaches, was reflected when richness was calculated at the reach level.

\section{Fish assemblage composition}

mCART analysis based on both raw presences (emphasising the number of occurrences) (Fig. 5) and row standardised presences (emphasising relative occurrences) (Fig. 6a) showed complex spatial structure, with all tree branchings being determined by estuary and reach. As with species richness, in neither case were the factors zone (wet/dry tropics) and region (the 7 groups of estuaries) influential in determining tree structure; the only instance of all 3 estuaries in a region remaining together in a terminal branch was for the 3 Bowling Green Bay estuaries for the relative occurrence data (Fig. 6a). Overall, the final tree groupings showed little obvious spatial consistency but appeared to represent haphazard assemblages of estuaries.

Relative occurrence profiles for groups in the terminal branches of the occurrence tree (Fig. 6b) show a fauna that is split into complex groupings. Two aspects seemed influential: the relative occurrence of common and rarer species, and the relative importance of different trophic groups. From the right, terminal splits show (1) 3 groups with a substantial proportion of occurrences of the most common species but relatively low occurrences of those occurring less frequently, (2) 3 groups with high occurrences of the most common species and relatively high occurrences of the less common species, (3) 2 groups with high occurrences of 


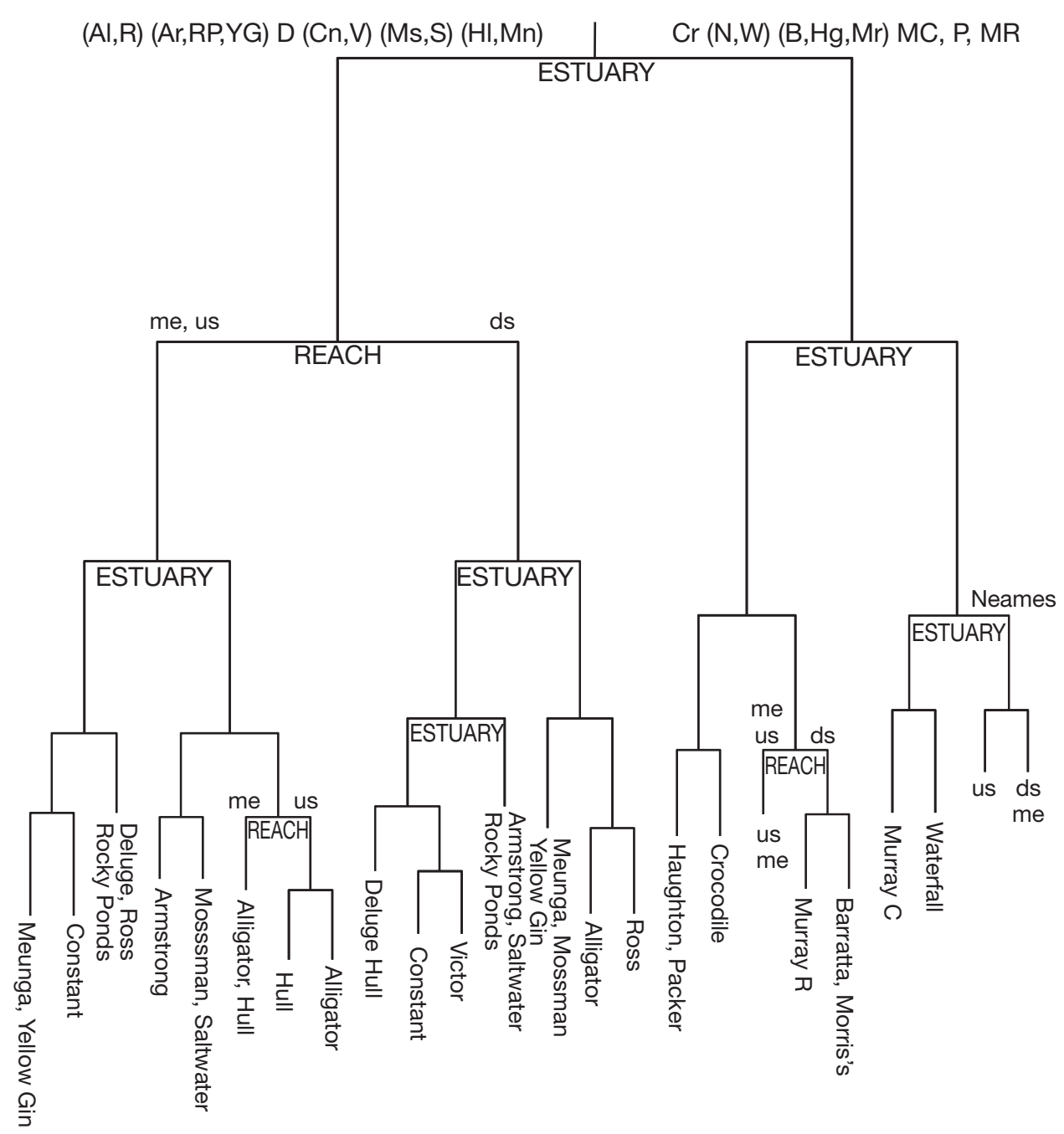

Fig. 5. Multivariate classification and regression trees (mCART) based on spatial variables explaining $35 \%$ of the variation in the occurrence of 24 species of fish that occurred in $>10 \%$ of estuary $\times$ reach combinations from 21 estuaries. Labels below terminal branches indicate the estuaries forming each group. Factors responsible for each split are indicated in uppercase letters below branch junctions, except where they are obvious from the terminal branch labels. Brackets around estuary codes at the primary split indicate estuaries from the same region. Codes above branch splits indicate the groups split where this is not obvious from terminal branch labels. Reach codes: $\mathrm{ds}=$ downstream, me = mid estuary, us = upstream. Estuary codes are given in Table 1

the herbivore Zenarchopterus buffonis, (4) 2 groups with similar profiles as the first 3 groups, and (5) 4 groups mainly dominated by 1 of 3 microcrustacean feeders (Leiognathus equulus, Ambassis vachelli, Pseudomugil signifer) and with relatively low numbers of the other species. Across this, there are apparent differences in the level of domination by microcrustacean or benthic feeders. For the number of occurrences tree (Fig. 5), reach splits mainly separated downstream from mid and upstream reaches, reflecting generally higher occurrences in downstream reaches. In contrast, upstream reaches were more often separated from downstream and mid reaches in the relative occurrence tree (Fig. 6a), indicating that compositions were more similar in mid and downstream areas.
Overall, the amount of variance explained by these trees was only moderate (raw presences $35 \%$, row standardised presences $31 \%$ ), reflecting relatively low correlations between species (maximum correlation = 0.47 between Leiognathus equulus and L. decorus).

MDS used to investigate the nature of upstream/ downstream differences (Fig. 7a) showed a clear pattern of spatial change. Thirteen of the estuaries showed faunal change between downstream and upstream reaches in approximately parallel directions, with shifts from high occurrences of Ambassis nalua and Thryssa hamiltonii downstream to high occurrences of Pseudomugil signifer and to a lesser extent Gerres filamentosus upstream (Fig. 7b). While Murray Creek showed no clear upstream/downstream change, the remaining 6 
(a)

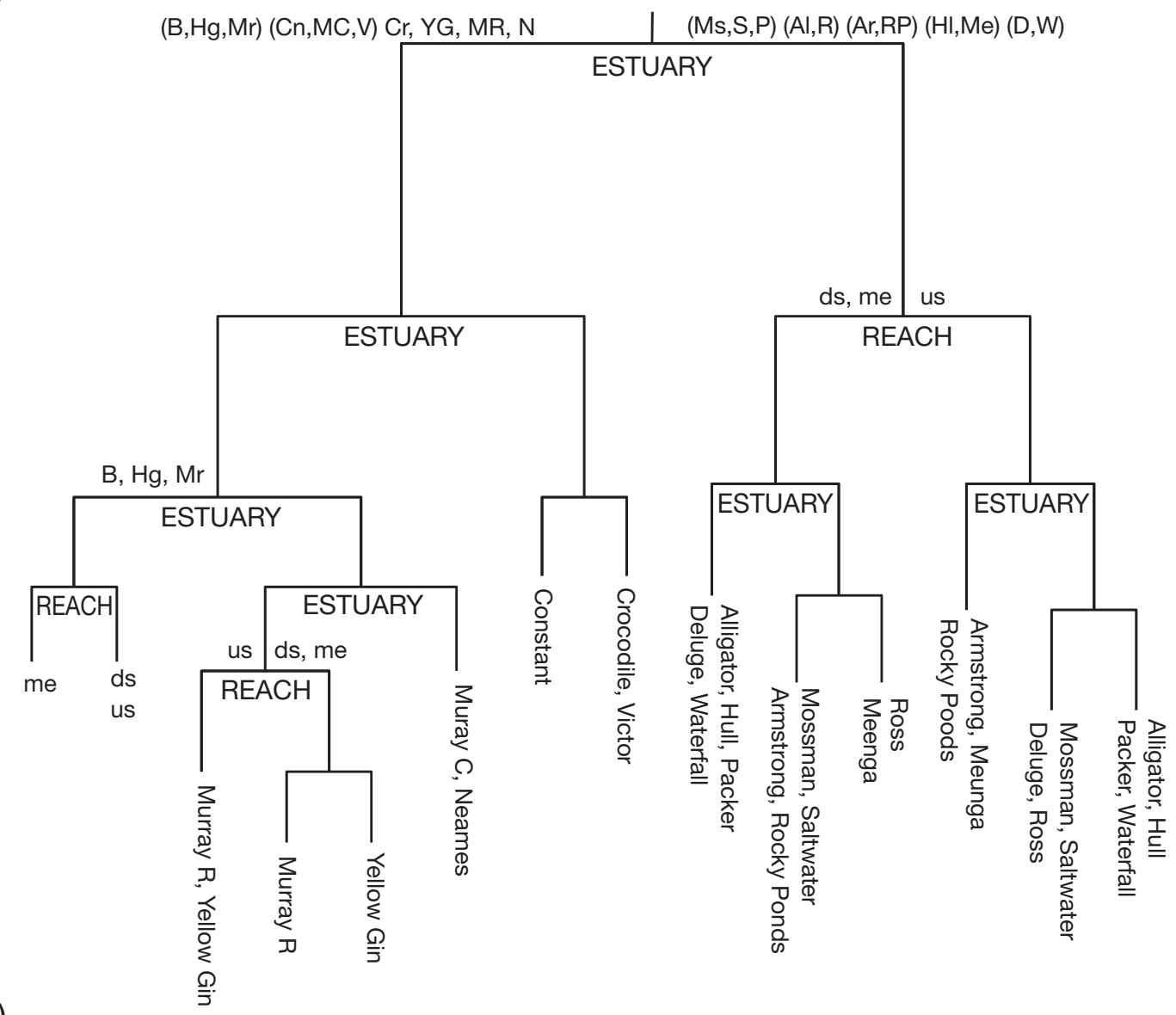

(b)

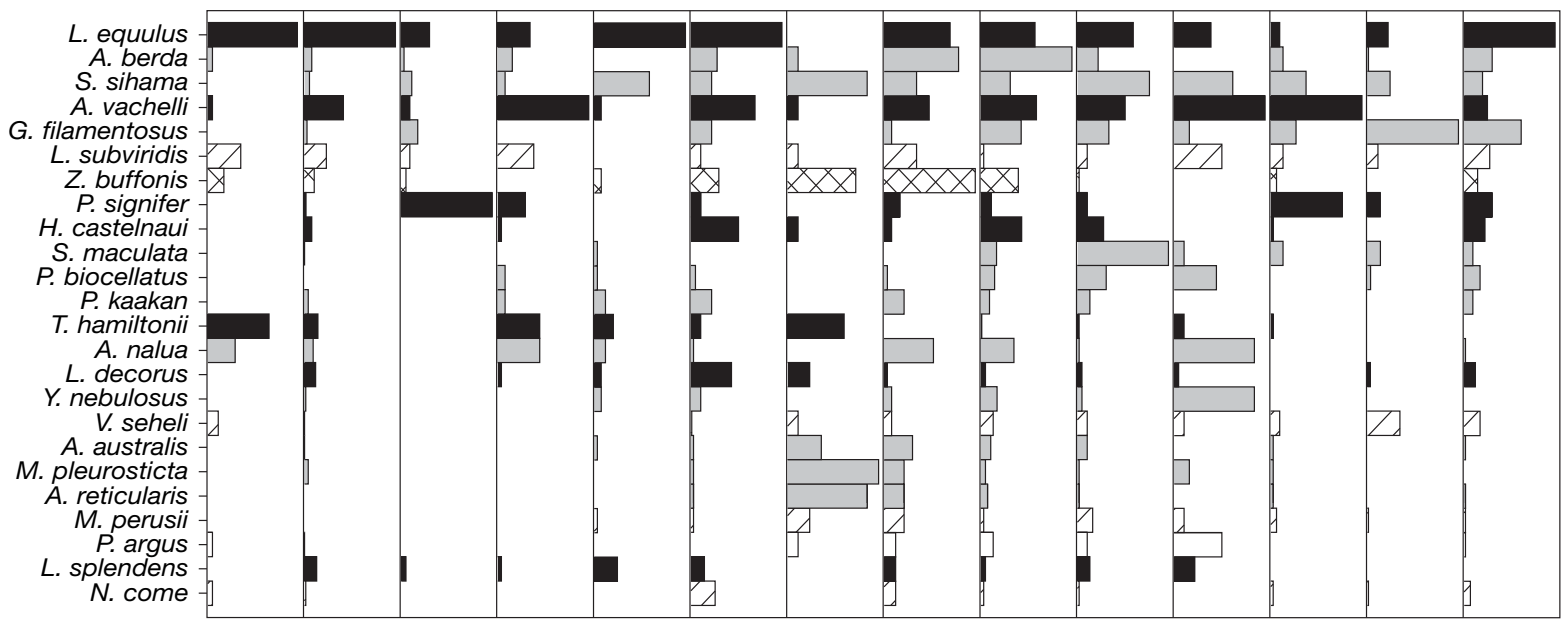

Relative frequency

Fig. 6. (a) Multivariate classification and regression trees (CART) based on spatial variables explaining $35 \%$ of the variation in the row standardized occurrence of 24 species of fish that occurred in $>10 \%$ of estuary $\times$ reach combinations from 21 estuaries. Labels below terminal branches indicate the estuaries forming each group. Factors responsible for each split are indicated in uppercase letters, except where they are obvious from the terminal branch labels. Estuary codes within parentheses at the primary split include estuaries from the same region. Codes above branch splits indicate the groups split where this is not obvious from terminal branch labels. Reach codes: ds = downstream, me = mid estuary, us = upstream. Estuary codes are given in Table 1. (b) Mean occurrence (out of 10 nets) profiles for each terminal branch in (a). Bar shadings: black = microcrustacean feeders, grey = benthic feeders, hatched = detritivores, cross-hatched $=$ herbivores, and white $=$ piscivores 


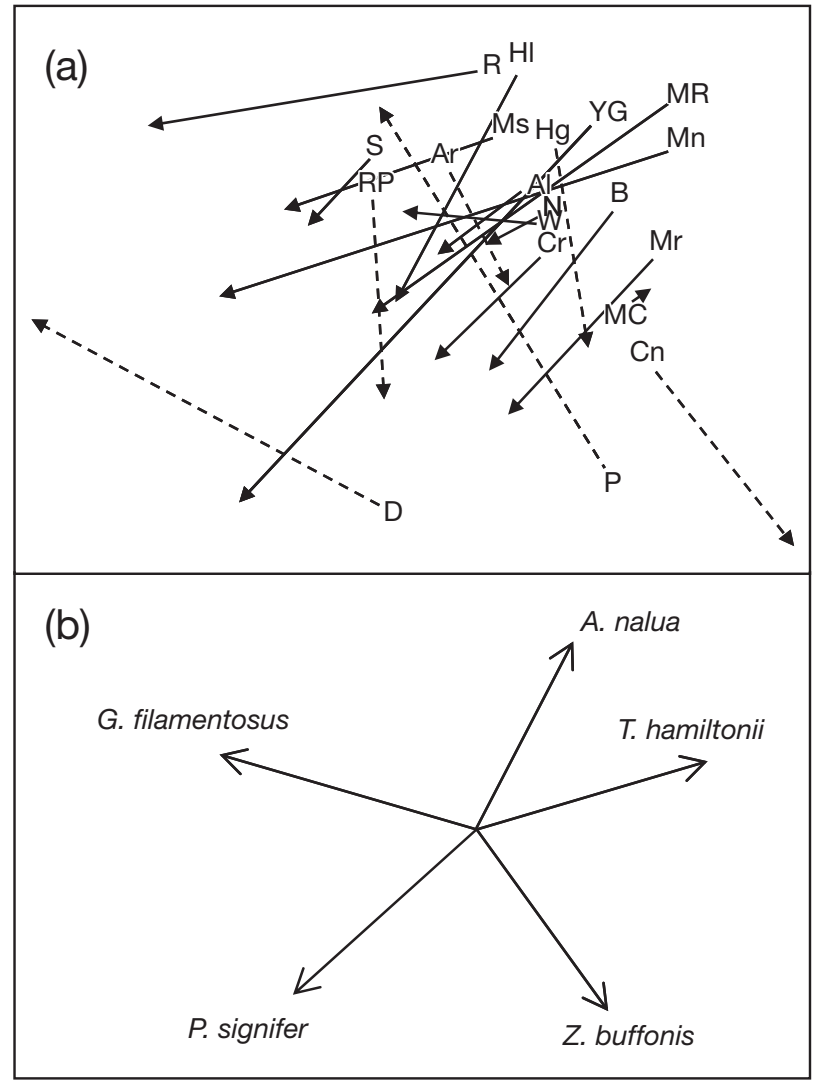

Fig. 7. Multidimensional scaling (MDS) ordination of data for fish assemblages at upstream and downstream sites of 20 estuaries (upstream data not collected for Victor Ck). (a) Ordination plots with downstream estuary reaches being indicated by codes (see Table 1) and the location of upstream sites by the heads of arrows originating from the respective estuary codes. (b) Vectors indicating the direction of greatest increase in occurrence of the 5 species with occurrences most highly correlated with the ordination space (maximum $\mathrm{R}^{2}=0.64$, for Gerres filamentosus)

estuaries where upstream reaches could be sampled showed change at right angles to the dominant pattern. These parallel patterns of change were not obvious in the regression tree analyses that are designed to reflect groupings rather than detect change relative to different starting points.

Univariate regression tree analyses produced valid trees for the occurrence of all common species except for Moolgarda perusii (Table 5) (mean variance explained $36 \%$ ). All primary splits were based on estuary identity except in the case of Pseudomugil signifer, which showed a dominant reach split with highest abundances upstream. As with the mCARTs, zone was not an important discriminator for any species, and region was generally not an influential variable. Within the high abundance branch of the primary split, only for 11 out of the 22 species did all 3 estuaries from

Table 5. Summary of univariate regression tree results for occurrences of species in at least $10 \%$ of sites. No. of estuary splits and no. of reach splits indicate the number of nodes differentiated on that factor. There was no valid spatial model for Moolgarda perusii

\begin{tabular}{|c|c|c|c|c|c|}
\hline Species & $\begin{array}{c}\text { Variance } \\
\text { explained (\%) }\end{array}$ & $\begin{array}{l}\text { Primary } \\
\text { split }\end{array}$ & $\begin{array}{l}\text { No. of } \\
\text { estuary splits }\end{array}$ & $\begin{array}{l}\text { No. of } \\
\text { reach splits }\end{array}$ & $\begin{array}{l}\text { Regions remaining coherent in a terminal } \\
\text { branch of high abundance primary split }\end{array}$ \\
\hline Leiognathus equulus & 31 & Estuary & 4 & 2 & Bowling Green \\
\hline Acanthopagrus berda & 36 & Estuary & 2 & 1 & \\
\hline Sillago sihama & 44 & Estuary & 3 & 2 & \\
\hline Ambassis vachelli & 27 & Estuary & 4 & 2 & \\
\hline Gerres filamentosus & 34 & Estuary & 1 & 1 & Hinchinbrook \\
\hline Liza subviridis & 27 & Estuary & 2 & 1 & Bowling Green, Cleveland, Rockingham \\
\hline Zenarchopterus buffonis & 30 & Estuary & 3 & - & Hillsborough \\
\hline Pseudomugil signifer & 46 & Reach & 2 & 1 & \\
\hline Herklotsichthys castelnaui & 31 & Estuary & 2 & 1 & \\
\hline Sillago maculata & 43 & Estuary & 5 & 2 & \\
\hline Psammogobius biocellatus & 35 & Estuary & 3 & 1 & \\
\hline Pomadasys kaakan & 38 & Estuary & 5 & 2 & \\
\hline Thryssa hamiltonii & 34 & Estuary & 2 & 1 & Bowling Green \\
\hline Ambassis nalua & 40 & Estuary & 3 & 1 & Cleveland \\
\hline Leiognathus decorus & 34 & Estuary & 2 & 1 & \\
\hline Yongeichthys nebulosus & 34 & Estuary & 1 & 1 & \\
\hline Valamugil seheli & 31 & Estuary & 2 & 1 & Cleveland \\
\hline Acanthopagrus australis & 26 & Estuary & 1 & - & Hillsborough \\
\hline Marilyna pleurosticta & 42 & Estuary & 3 & 1 & \\
\hline Arothron reticularis & 47 & Estuary & 2 & - & Hillsborough \\
\hline Pseudorhombus argus & 37 & Estuary & 2 & 1 & Cleveland \\
\hline Leiognathus splendens & 41 & Estuary & 3 & 1 & \\
\hline Nematalosa come & 34 & Estuary & 2 & 1 & \\
\hline
\end{tabular}


1 of the 7 regions remain together through to a terminal branch, and only in 1 instance (for Liza subviridis) did $>1$ region remain coherent in terminal nodes. What is notable about the univariate spatial analyses is the lack of consistent patterns of estuary groupings among species, suggesting that the complex multivariate groupings seen in the multivariate trees are driven by diverse species-level responses.

\section{Site-level physical variables}

Valid regression trees could be produced for the multivariate assemblage, species richness and 14 species using site-level physical variables. These generally explained less of the variation (mean $=27 \%$ ) than the spatial data set. Most variables showed high species-to-species variation; however, single categories of cross channel profile (low relief basin) and sinuosity (high) predicted high occurrences of all the species they influenced.

\section{Estuary-level ecological variables}

Estuary-level ecological variables (Table 6) explained much more of the variation in the multivariate assemblages (35\% downstream, $44 \%$ upstream) and in species richness (24\% downstream, $46 \%$ upstream) than did site-level physical variables. Intertidal area, subtidal area and sediment index were the most important predictors of the multivariate pattern for downstream reaches, with mangrove area and estuary classification being the best predictors of species richness. Intertidal area, saltmarsh area and sediment index were the best predictors of both multivariate assemblage structure and species richness for upstream reaches.

Valid univariate regression trees based on estuarylevel ecological variables could be constructed for 20 of the 29 species with high occurrences in downstream reaches, and for 14 of the 17 species commonly occurring in upstream reaches. These explained a similar $($ downstream mean $=33 \%$ ) or greater (upstream mean $=42 \%$ ) amount of variability than the spatial data set. All variables except 'influence at mouth' were important for at least 1 species but 2 variables (mangrove area and sediment index) were influential in a substantial proportion of cases (both $44 \%$ ). While the directions of influence (i.e. high values leading to high or low occurrences) of most areal variables were inconsistent, high mangrove area matched with high occurrences of 14 of the 15 species it influenced, indicating a consistent positive influence of mangroves. The direction of influence of sediment index was species specific; however, for 5 of the 6 demersal species it influenced
(Psammogobius biocellatus, Pseudorhombus argus, Sillago maculata, S. sihama and Yongeichthys nebulosis), occurrences were higher in coarser sediments.

Estuary-scale potential for impact

There was no obvious relationship between either species richness or mean CPUE per estuary and any of the potential impact variables. In fact, the most pristine estuary (Deluge Inlet) had relatively low species richness, while many sites with much greater potentials for impact had much higher mean species richness.

\section{DISCUSSION}

In a broad sense, a typical fish assemblage, dominated by Ambassidae, Clupeidae, Gobiidae, Haemulidae, Leiognathidae, Mugilidae, Sillaginidae, Sparidae and Tetraodontidae, was identifiable across the 21 estuaries spanning some $650 \mathrm{~km}$ of the coast of northeast Queensland, Australia. Despite possessing a common fauna, the estuaries showed considerable variation in details of the faunal composition, species richness and individual species occurrence. This variation had little to do with an estuary's position relative to other estuaries or its climatic zone (wet vs. dry tropics). Rather, variability focussed at the estuary-to-estuary scale, with groupings of estuaries consistently comprising systems from different regions and zones. The complex estuary-to-estuary variation in assemblage structure was largely a product of contrasting spatial patterns displayed by different species. Few species showed even moderately correlated distributions, as reflected in the lack of consistent patterns of estuary groupings among species, suggesting species-specific differences in responses to the biotic and abiotic environments. In turn, the diverse assemblage and species patterns seemed to be influenced in complex ways by contrasting responses to physical and ecological variables. Matching with the dominant estuary-level biotic variability, estuary-level ecological variables generally had greater power in explaining faunal differences than site-specific physical variables that generally explained less of the variation.

The pattern of overall faunal similarity but extensive estuary-to-estuary variation in fish assemblage structure appears to be a feature of estuaries in tropical northeastern Australia. The compositions of the smallfish assemblages of the 21 study estuaries are consistent with that reported in other studies of northeastern tropical Australian estuaries (e.g. Robertson \& Duke 1990, Sheaves 2006). Similarly, the among-estuaries variability seen in the present study is similar to that re- 
Table 6. Influence (\%) of estuary-level ecological variables on the occurrence of species in (a) downstream and (b) upstream reaches. For the multivariate tree variables, $\star$ : relative importance $>80 \%$. b: barrier, c: coarse, f: fine, h: high, i: intermediate, l: low, m: minor barrier, n: near, s: seasonal estuary, t: tidal creek, unsinuous. $(\downarrow)$ variables not included in the model that have a relative importance $>80 \%$

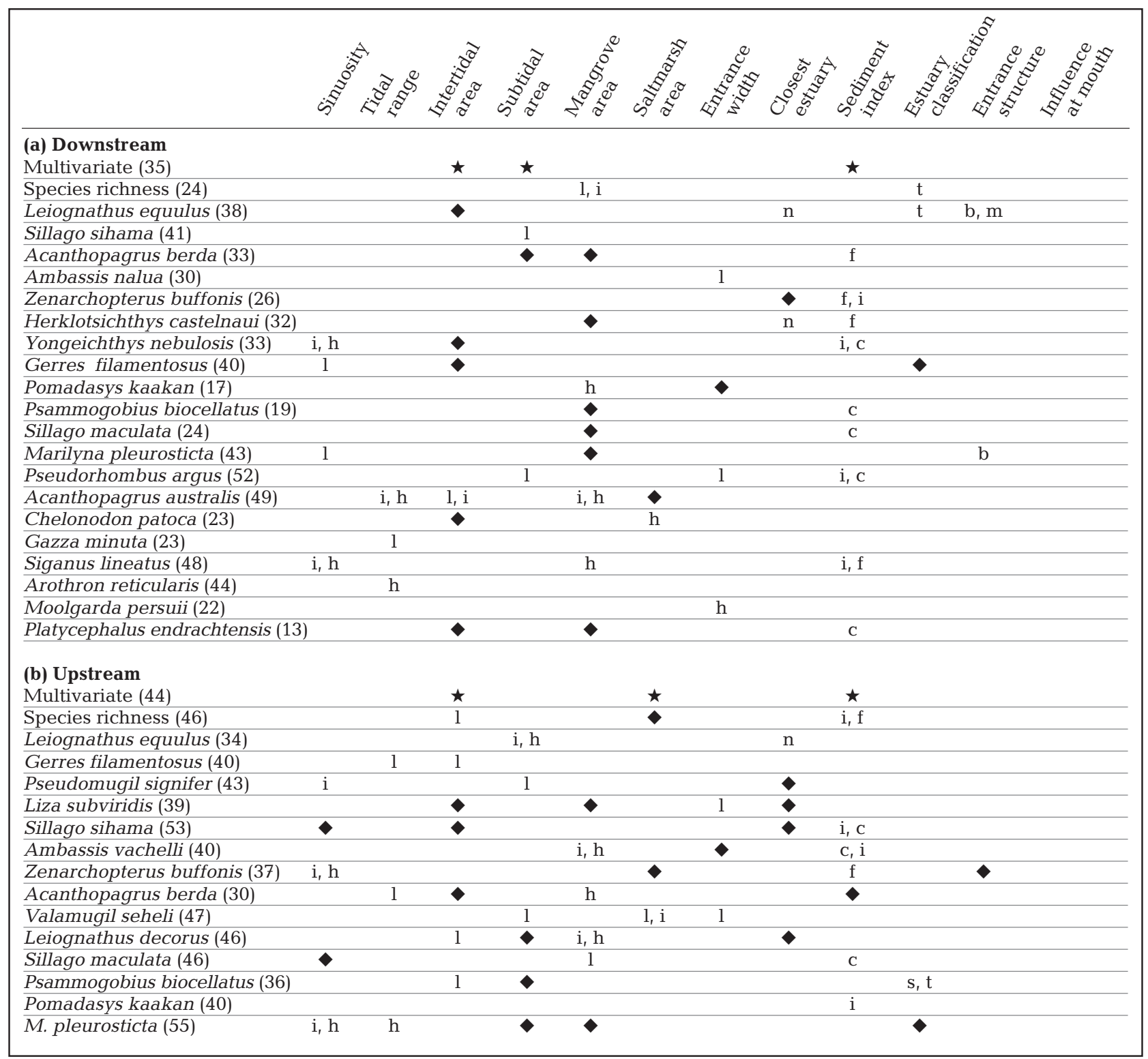

ported in previous extensive spatial studies in the region using other gear types. This includes 9 estuaries sampled with seine nets (Sheaves 2006), and 11 estuaries sampled with gill nets (Ley 2005). The results of these extensive studies suggest that among-estuaries differences reported in previous studies that included just a few estuaries (Robertson \& Duke 1990, Sheaves 1998) was due to estuary-to-estuary variability rather than systematic spatial differences at the scales studied.

It seems logical for climatic zones (wet/dry tropics) and proximity to other study estuaries (occurrence in the same bay) to have strong influences on faunal sim- ilarity, but this does not seem to be the case in tropical northeastern Australia. Neither factor provided clear explanations for the multivariate assemblage, species richness or individual species distributions, again reflecting the results of previous extensive spatial studies (Ley 2005, Sheaves 2006). Perhaps the lack of a wet/ dry tropics split should be expected. Both wet and dry tropics experience extensive seasonal changes in salinity, with the real difference being the extent to which the wet and dry phases dominate. In this case, it might not be surprising that fish fauna adapted to meet the challenges of living in a rapidly fluctuating envi- 
ronment, with periodic saline and freshwater phases (Sheaves 1996), is not greatly influenced by salinity regimes. The lack of response to proximity is more difficult to explain but indicates local-level responses of a widespread fauna at the scale of estuaries rather than regions.

Estuary-level ecological variables had greater explanatory power than site-level physical variables and, importantly, are focussed at the scale that accounted for the greatest proportion of systematic variability. This scale is ecologically significant because it is the scale at which the major ecological structuring processes are focussed (Mohd Norowi et al. 1999) and is thus the scale at which characteristic faunal patterns are determined (Azovsky 2000). Consequently, variables that have strong explanatory power at this focal scale are likely to be important in determining the major features of the spatial pattern. Two variables (mangrove area and sediment index) were particularly influential across the analyses and were important explanatory variables for the multivariate pattern, species richness and close to half of the individual species. Occurrences of most species that were influenced by mangrove area tended to rise as total mangrove area increased, which is exactly the situation that would be expected if the refuge and feeding values of mangroves were important to the fish assemblages studied (Sheaves 2005). Benthic species that responded to sediment occurred most often in estuaries dominated by coarse sandy substrate. Most of these were macrobenthos feeders and their higher occurrence over coarser sediments matches the higher abundance of their main prey (Wilson \& Sheaves 2001) in sandy sediments (L. Ortiz Guerra pers. comm.).

Variables related to the structure of the estuary entrance (entrance structure, influence at mouth) had little explanatory power but this was not surprising. Since tidal ranges are at least $3 \mathrm{~m}$ throughout the study area, there are unlikely to be any real impediments to either larvae or migrating adults entering most estuaries. Similarly, indices of anthropogenic impact had no explanatory power, probably because levels of development in the study systems are insufficient to produce observable effects against the background of underlying faunal variability.

\section{IMPLICATIONS}

This study represents the most spatially extensive study so far of tropical estuarine fish fauna utilising a single sampling approach. It also includes a greater number of spatial scales than most previous studies. However, in producing this extensive body of spatial data, the study accepted a number of limitations.
Firstly, the study was limited to one point in time and thus represents a single temporal snapshot. Although there was little faunal variation over the study period at the 5 sites that were resampled, and despite the fact that previous work (Sheaves 2006) suggested little year-to-year variation in the dry season fauna of northeastern Australian estuaries, any temporal extrapolation needs to be treated with caution. Additionally, while using only a single sampling gear allowed spatial comparison that was unbiased by gear differences, it means that only part of the fauna was well represented. In particular, smaller size classes were well represented but larger individuals were likely to be underrepresented, particularly in the case of more mobile species. These limitations mean that the patterns produced and the ecological understanding gained need to be treated as tentative. Finally, the lack of any long-term physical data for the estuaries studied meant that the physical descriptions used were likewise only snapshots in time. Clearly, extensive timeintegrated data are required to fully understand the physical nature of these estuaries and allow definitive evaluation of the impact of the environment on assemblage patterns.

Despite these caveats, the study provides a broadbased understanding of spatial patterns in taxonomically diverse tropical estuarine fish assemblages, and shows that the apparently 'random' variability is at least partially explicable. At a proximal level, complex assemblage patterns seem to result from interacting species specific processes, while at a deeper level, these species-level patterns seem to be driven by well understood ecological processes. The results also provide clear directions for future validating studies and a basis for developing testable conceptual models that can lead to the development of deeper understanding. Moreover, the fact that a number of estuary-level ecological variables provided good explanation of the complex spatial patterns typical of tropical estuarine fauna (Ley 2005, Sheaves 2006) indicates the value of developing estuary-scale explanatory variables that relate to specific ecological processes rather than relying on the physical variables that usually provide the basis for typological description of estuaries. Additionally, the lack of any clear influence of climatic zones (wet/dry tropics) or of proximity to other sites in explaining spatial patterns highlights the continual need for careful evaluation of paradigmatic understanding.

The lack of relationship between faunal pattern or species richness and climatic zones, proximity to other estuaries or how pristine an estuary appears to be, has major implications for the evaluation of ecosystem health in tropical estuaries. It suggests that the idea of using 'pristine' or 'unimpacted' sites as controls for evaluation and monitoring is problematic. It cannot be 
assumed that the fish fauna of an impacted estuary would resemble that in a nearby unimpacted site if the impact was absent. Furthermore, it cannot be assumed that variables that are important measures of ecosystem health in other ecosystems are suitable measures in tropical estuaries. For example, high fish species richness and abundance are recognised as sensitive measures of ecosystem condition in freshwater systems of tropical Australia (Kennard et al. 2006); however, the lack of a relationship between richness or presence per net and the potential impact status of northeastern Australian estuaries suggests that these measures are generally not appropriate for the systems studied. Perhaps careful matching of typological profiles would allow these measures to be applied to 'similar' systems, but the complexity of tropical estuarine fauna makes this unlikely. However, although measuring absolute ecosystem health of these estuaries is difficult, the consistency of temporal patterns (Sheaves 2006) could make measuring changes relative to an estuary's initial status likely to be a viable proposition.

Acknowledgements. We thank 3 anonymous reviewers for their insightful and helpful comments, and the volunteers whose assistance made the extensive fieldwork possible. This work was conducted in accordance with institutional, national and international guidelines concerning the use of animals in research under ethics permit A1210.

\section{LITERATURE CITED}

Anon (2008) OzCoast and OzEstuaries data base. Coastal Zone Australia

Arnold GP, Metcalfe JD, Holford BH, Buckley AA (1997) Availability and accessibility of demersal fish to survey gears: new observations of natural behaviour obtained with electronic data storage tags. ICES CM/W:11

Azovsky AI (2000) Concept of scale in marine ecology: linking the words or the worlds? Web Ecol 1:28-34

- Blaber SJM (1980) Fish of the Trinity Inlet system of north Queensland with notes on the ecology of fish faunas of tropical Indo-Pacific estuaries. Aust J Mar Freshw Res 31: 137-146

Blaber SJM, Brewer DT, Salini JP (1989) Species composition and biomasses of fishes in different habitats of a tropical northern Australian estuary: their occurrence in the adjoining sea and estuarine dependence. Estuar Coast Shelf Sci 29:509-531

Breiman L, Friedman J, Olshen R, Stone C (1984) Classification and regression trees. Wadsworth, Pacific Grove, CA

De'ath G (2002) Multivariate regression trees: a new technique for modeling species-environment relationships. Ecology 83:1105-1117

Downing, JA (1991) Biological heterogeneity in aquatic ecosystems. In: Kolosa J, Pickett STA (eds) Ecological heterogeneity. Springer-Verlag, Berlin, p 160-180

Holling CS (1992) Cross-scale morphology, geometry, and dynamics of ecosystems. Ecol Monogr 62:447-502

Johnston R, Sheaves M (2007) Small fish and crustaceans demonstrate a preference for particular small-scale habitats when mangrove forests are not accessible. J Exp Mar Biol Ecol 353:164-179

Johnston R, Sheaves M (2008) Cross-channel distribution of small fish in tropical and subtropical coastal wetlands depends on their trophic and taxonomic identities and on wetland depth. Mar Ecol Prog Ser 357:255-270

Kennard M, Pusey B, Arthington A, Harch B, Mackay S (2006) Development and application of a predictive model of freshwater fish assemblage composition to evaluate river health in eastern Australia. Hydrobiologia 572:33-57

Legendre P, Legendre L (2003) Numerical ecology. Elsevier, Amsterdam

- Levin SA (1992) The problem of pattern and scale in ecology. Ecology 73:1943-1967

> Ley JA (2005) Linking fish assemblages and attributes of mangrove estuaries in tropical Australia: criteria for regional marine reserves. Mar Ecol Prog Ser 305:41-57

Manley PN, Zielinski WJ, Schlesinger MD, Mori SR (2004) Evaluation of a multiple-species approach to monitoring species at the ecoregional scale. Ecol Appl 14:296-310

Marchal E, Petitgas P (1993) Precision of acoustic fish abundance estimates: separating the number of schools from the biomass in the schools. Aquat Living Resour 6:211-219

McCune B, Grace J (2002) Analysis of ecological communities. MjM Software Design, Gleneden Beach, OR

Mohd Norowi H, Perry JN, Powell W, Rennolls K (1999) The effect of spatial scale on interactions between two weevils and their food plant. Acta Oecol 20:537-549

- Newlands NK, Lutcavage ME, Pitcher TJ (2006) Atlantic bluefin tuna in the Gulf of Maine, I. Estimation of seasonal abundance accounting for movement, school and school-aggregation behaviour. Environ Biol Fishes 77 : 177-195

Robertson AI, Duke NC (1990) Mangrove fish-communities in tropical Queensland, Australia: spatial and temporal patterns in densities, biomass and community structure. Mar Biol 104:369-379

> Sheaves M (1992) Patterns of distribution and abundance of fishes in different habitats of a mangrove-lined tropical estuary, as determined by fish trapping. Aust J Mar Freshw Res 43:1461-1479

Sheaves M (1995) Effect of design modifications and soak time variations on Antillean-Z fish trap performance in a tropical estuary. Bull Mar Sci 56:475-489

Sheaves M (1996) Do spatial differences in the abundance of two serranid fishes in estuaries of tropical Australia reflect long-term salinity patterns? Mar Ecol Prog Ser 137: 39-49

Sheaves M (1998) Spatial patterns in estuarine fish faunas in tropical Queensland: a reflection of interaction between long-term physical and biological processes? Mar Freshw Res 49:31-40

> Sheaves M (2005) Nature and consequences of biological connectivity in mangrove systems. Mar Ecol Prog Ser 302: 293-305

> Sheaves M (2006) Scale-dependent variation in composition of fish fauna among tropical estuarine sandy embayments. Mar Ecol Prog Ser 310:173-184

Sheaves M, Johnston R, Abrantes K (2007) Fish fauna of dry tropical and subtropical estuarine floodplain wetlands. Mar Freshw Res 58:931-943

Wilson JP, Sheaves M (2001) Short-term temporal variations in taxonomic composition and trophic structure of a tropical estuarine fish assemblage. Mar Biol 139:787-796 